\title{
Putative Receptors for Gravity Sensing in Mammalian Cells: The Effects of Microgravity
}

\author{
Michele Aventaggiato ${ }^{1}$, Federica Barreca ${ }^{1}$, Enza Vernucci ${ }^{2}$, Mariano Bizzarri ${ }^{1}{ }^{1}$, \\ Elisabetta Ferretti ${ }^{1}{ }^{\mathbb{D}}$, Matteo A. Russo ${ }^{3}$ and Marco Tafani ${ }^{1, *}$ \\ 1 Department of Experimental Medicine, Sapienza University of Rome, 00161 Rome, Italy; \\ micavent@hotmail.it (M.A.); federica.barreca@uniroma1.it (F.B.); mariano.bizzarri@uniroma1.it (M.B.); \\ elisabetta.ferretti@uniroma1.it (E.F.) \\ 2 Department of Internistic Clinical Sciences, Anesthesiologic and Cardiovascular Sciences, Sapienza \\ University of Rome, 00161 Rome, Italy; enza.vernucci@gmail.com \\ 3 MEBIC Consortium, San Raffaele Rome Open University, 00166 Rome, Italy; \\ matteoantoniorusso44@gmail.com \\ * Correspondence: marco.tafani@uniroma1.it; Tel.: +39-0649918234
}

Received: 19 February 2020; Accepted: 11 March 2020; Published: 17 March 2020

\begin{abstract}
Gravity is a constitutive force that influences life on Earth. It is sensed and translated into biochemical stimuli through the so called "mechanosensors", proteins able to change their molecular conformation in order to amplify external cues causing several intracellular responses. Mechanosensors are widely represented in the human body with important structures such as otholiths in hair cells of vestibular system and statoliths in plants. Moreover, they are also present in the bone, where mechanical cues can cause bone resorption or formation and in muscle in which mechanical stimuli can increase the sensibility for mechanical stretch. In this review, we discuss the role of mechanosensors in two different conditions: normogravity and microgravity, emphasizing their emerging role in microgravity. Microgravity is a singular condition in which many molecular changes occur, strictly connected with the modified gravity force and free fall of bodies. Here, we first summarize the most important mechanosensors involved in normogravity and microgravity. Subsequently, we propose muscle LIM protein (MLP) and sirtuins as new actors in mechanosensing and signaling transduction under microgravity.
\end{abstract}

Keywords: microgravity; mechanosensor; cystein-rich proteins; sirtuins; cellular and molecular rehabilitation; muscle LIM protein

\section{Microgravity Effects in Different Tissues}

Gravity has played a very important evolutionary role in the development of life on Earth, forcing the organisms to evolve the capacity to translate gravity force into biochemical stimuli, responsible for intracellular and molecular changes, conditioning the architectural organization of cytoplasm and nucleus, and then the adaption of organisms to this constant and pervasive force.

For this reason, both the reduction of gravity (or microgravity) experienced, for example, on the short/long-term stay in the ISS (International Space Station) and hypergravity (for instance, hyper acceleration in the space flights) represents singular extreme conditions in which a number of cellular changes have been observed.

Prolonged microgravity causes several physiopathological effects on tissues such as skeletal, cardiac, smooth muscle, bone, and the nervous system [1,2]. In addition to cellular/molecular changes, in the cardiovascular system, a situation called "fluid shift" takes place where blood accumulates in the head and in the chest region for the absence or reduction of gravity, while on earth blood tends to 
stay in the lower segments of the body, especially the legs. In this situation, microgravity causes a highly specific response of cardiovascular system with a decrease in plasma volume and circulating blood. Otherwise, it causes an increase of erythrocytes and hemoglobin mass with a decrease in the arterial diastolic pressure of the blood [3].

A large number of studies have also detailed the negative effects of real and simulated microgravity on the immune system and countermeasures have been suggested [4]. Several experiments conducted in rats demonstrated that spaceflight causes a lymphoid organs hypoplasia and alteration in blastogenesis [5]. More recently, microgravity has been shown to reduce the number, differentiation, and polarization of macrophages by affecting the Rat Sarcoma (RAS)/Extracellular signal-regulated kinase (ERK)/Nuclear factor kappa-light-chain-enhancer of activated B cells (NFkB) pathway [6]. Moreover, the dendritc maturation and activation of T-cell is also reduced after prolonged microgravity exposure [7]. On the other hand, microgravity increased the resistance of T-cells to dendritic cell activation [8]. Furthermore, cytokine production, such as interferon $\alpha / \beta$, is altered after spaceflight [9], and also the immunoglobulin level shows a little increase in total concentration after long-term spaceflight [10]. These data, taken together, suggest that reduction of stress, increased exercise, adequate diet, etc., should be implemented during prolonged space flights in order to minimize adverse effects on the immune system.

Moreover, long-term missions in space accelerate muscle atrophy [11] that involves skeletal/postural muscle. In fact, under microgravity conditions, the skeletal muscle system is characterized by "deconditioning" with the loss of mass, force, and power with abnormal reflex patterns [12] that limit the astronaut's ability to work in the weightlessness condition. Physiological changes in muscle are due to a combination of factors like increased degradation of muscle proteins without the substitution of newly expressed proteins normally operating as a maintenance mechanism at normogravity on the earth; this will be worsened by subsequent changes of the neuromuscular control of movement strictly connected with profound alterations in muscle fibre size and organization. This mechanism is suggested by another characteristic finding that affects skeletal and cardiac muscle: the transition in myosin heavy chain (MHC) isoform expression, especially observed in rodents, with a downregulation of slow type I MHC and an increased expression of fast type IIx MHC [13]. It has also been assumed that humans can undergo a similar transition, explaining the clinical changes observed in astronauts after long-term spaceflights. More studies both in human and animal models are needed to clarify this situation [14]. Structural muscle damages underlying the above condition and associated with microgravity are characterized by less dense $Z$ and $C$ bands (loss of proteins for the anchorage of actin and myosin filaments, respectively), myofibril and actin/myosin filaments decrease with Sarcomere disorganization, sarcoplasmic reticulum and sarcolemma disorganization, and several lesions of endomysium [12].

Usually, these pathological conditions are reversible upon return in normogravity conditions. Although $15 \%$ of the skeletal/cardiac muscle mass is lost during prolonged spaceflight, the contractile mass is recovered after a variable period of returning to normogravity conditions [15]. Nevertheless, unloading causes severe conditions, such as microcirculatory changes and interstitial oedema [11] with a consequent decrease in force, mass, and power in muscle contraction [16-18].

In humans, the most important muscles involved in microgravity-associated changes are the gastrocnemius, knee extensor, soleus, and tibialis; muscles that are in contact with the ground and suffer the effects of the free fall in microgravity conditions [19].

It is worth noting that bone tissue is also affected by microgravity. Bone tissue is characterized, on average, by a $1 \%-2 \%$ mass loss for every month spent in weightlessness with a substantial decrease in mineral density (osteoporosis). These changes appear to be site-specific because they are especially evident in the weight-bearing bones [20]. This clinically relevant situation reflects microscopic/molecular changes with a decrease in the master genes of bone differentiation, such as RUNX2, and an increase in adipose tissue markers, such as PPAR $\gamma$, leptin, adipsin, and Glut4. These molecular changes are responsible for the increase in bone fragility and the decrease in bone 
elasticity, as demonstrated by computed tomography (QCT), speed of sound relevation (SOS), and broadband ultrasound attenuation (BUA). Collet et al. measured the levels of the factors that are involved with bone formation (osteocalcin, alkaline phosphatases, precollagen type I) and the markers of bone resorption like galactosyl hydroxylysine, pyridinoline, and deoxypyridinoline [21], reporting an increase in the markers of bone resorption and a decrease in the markers involved in bone formation.

Bone is composed mainly by osteocytes, the differentiated form of osteoblasts, by osteoclast and mesenchymal stem cells (MSCs). MSCs can differentiate in several tissue types, such as fat, muscle, bone, cartilage, and marrow stroma [22], according to the stiffness of their extracellular environment and on the basis of several molecules and stimuli that come from the organism [23]. Several studies have revealed that microgravity causes adipogenesis, while mechanical stimuli can cause bone formation [24]. Lin et al. have demonstrated that osteocytes are involved in bone loss in microgravity conditions [25]. In fact, after a two-week flight, osteocytes apoptosis occurs with an increase in the activity of osteoclasts, responsible for bone resorption and with an increase in their activity in microgravity conditions [26,27].

Nevertheless, bone tissue is also characterized by a recovery after spaceflight, although this process may be longer than the mission duration [28]. Furthermore, weight bearing bones like femurs are more affected by microgravity than less weight bearing bones, like vertebrae [29,30], causing a different recovery strictly related to the bone type. After landing, in fact, many adaptations occur, like a normalized bone tissue resorption and an increased bone formation [28].

Several parameters of bone tissue are often compared in normogravity and microgravity conditions in order to obtain an overview of these different situations, such as the crystallinity index, mineral maturity, carbonation, and the mineralization index, but its results are very important to consider, especially the collagen quality because collagen represents the most important organic component of bone matrix. In fact, collagen fibre orientation is modified by the loading direction [31].

\section{Mechanotransduction}

The transduction of a mechanical force into biological signals is obtained through conformational changes in the "mechanosensory molecules" or gravireceptors. These molecules are characterized by two ends: the first is able to strictly connect to many fixed structures, such as the cytoskeleton, anchorage blocks, or extracellular matrix, while the other end modifies its conformation under mechanical stimuli [32].

In the last decade a large number of molecules have been identified as mechanosensors. Some cell types have evolved singular structures, specialized in the response to gravity, such as otoliths in the hair cells of the vestibular system and statoliths in plants, both of which are involved in transducing the mechanical stimulus to a mechanosensitive protein generating the biological signal [33].

Additionally, touch and hearing depend on mechanical forces detected by specific receptors (sensory neurons) that are able to sense mechanical changes induced by touch pressure or tympanic deformation, respectively. The hair cells of the inner ear possess classical cilia on their surfaces, which are deformed by acoustic wave acting on tympanic membrane and endolymph. In the inner ear, two anatomic structures mediate the gravity sensing and final mechanotransduction: the utricle and saccule [34]. Linear acceleration and gravity are sensed through the shear forces produced by the otoconia on the stereocilia and produce the transduction of the gravity or acceleration signals reaching acoustic areas of the brain. In particular, movement of the cilia causes the opening of mechanosensitive cation channels, then an altered membrane potential of the hair cells and a release of several neurotransmitters send information to the brain. Although this system has been roughly described, the molecules involved in this cascade are still not well known, and more studies must be conducted in order to clarify all molecular details [33].

Additionally, the bone skeleton is able to respond to mechanical and gravity stimuli through the presence of dendritic processes in the canaliculi structures between different osteocytes, cells that represent the differentiated stage of osteoblast [35]. Osteoblast activity is chiefly responsible for 
bone formation. Moreover, osteoclasts, a bone-specific form of macrophage, seem to be able to sense mechanical stimuli and play a role in mechanotransduction that is involved in bone maintenance through signals producing bone resorption [36]. It is still unclear what molecules actually generate the signal cascade both in osteocytes and in osteoclasts. Osteocytes can communicate by several second messengers released in the canaliculi, such as nitric oxide (NO), ATP, prostaglandins, and $\mathrm{Ca}^{2+}$ [37-40]. Osteoclasts express integrins interacting with the extracellular matrix (ECM)/mineral matrix molecules and a proton pump acidifying the microenvironment defined by integrins adhesion (Figure 1).

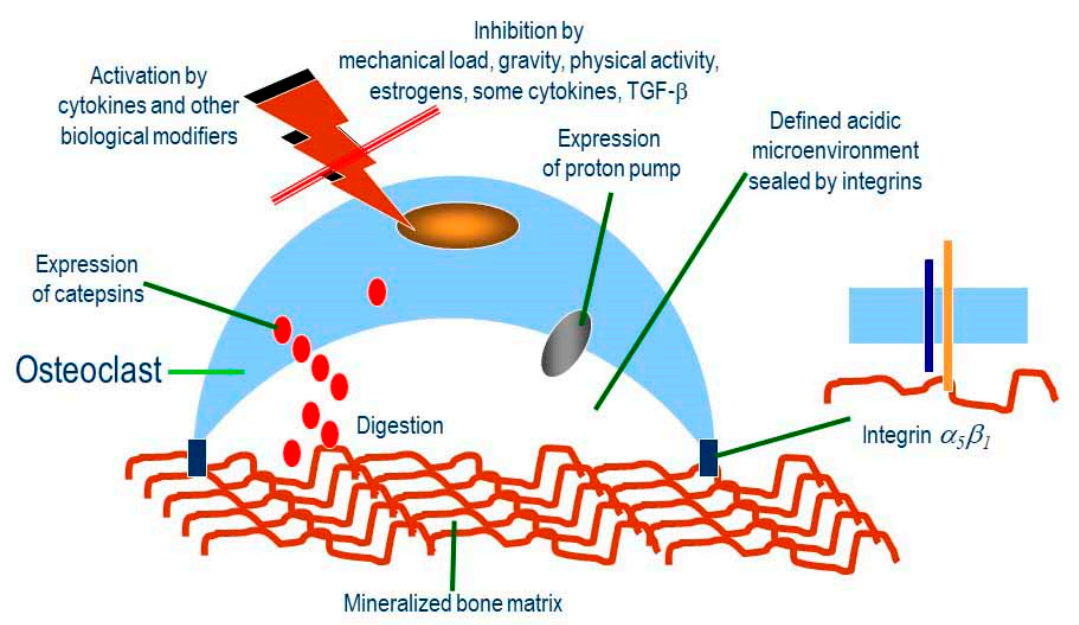

Figure 1. Role of osteoclasts in osteoporosis and the inhibiting effects of mechanical load, gravity, and physical activity. Bone resorption is performed by osteoclasts when activated by certain cytokines, hormones, and the absence of mechanical stimulation (load, gravity, physical activity). In these conditions, cathepsins, $\mathrm{H}^{+}$-dependent plasmamembrane ATP-ase and $\alpha_{5} \beta_{1}$ integrin are expressed. The $\alpha_{5} \beta_{1}$ integrin interact with the extracellular matrix (ECM) molecules of the mineralized bone matrix, forming a segregated vacuole, where cathepsins and protons are secreted; cathepsins are activated by an acidic environment, demolishing mineralized matrix lining the segregated vacuole. Mechanical forces, including gravity, estrogen, TGF- $\beta$, and certain cytokine signalling, reduce or block the expression of integrin, proton pump, and cathepsin, preventing the digestion of the bone matrix. On the other hand, it is well known that absence of estrogen signalling (menopause), physical activity (sedentary life style), and gravity (microgravity) are conditions highly favouring osteoporosis.

Strictly connected to the bone, skeletal muscle tissue is susceptible to mechanical input and is able to respond to the mechanical stretch. In fact, these stimuli can modulate a differentiation or proliferation of the muscle cells [41,42].

Endothelial cells, bound to the blood vessels, are exposed to the blood flow that causes a shear stress on the cells [32]. Differences in the blood flow can alter the shear stress regulating a different gene expression profile in endothelial cells that can result in pathologic conditions like atherosclerosis. In this context, PECAM-1, a mechanosensory molecule tightly connected with cytoskeleton, vimentin, and actomyosin, in shear stress conditions, activates the Src family of kinase [43].

Under these same conditions, platelet can be activated following a perturbation of blood shear stress in the lumen of blood vessels [44]. Mechanical forces on the surface of the cells cause deformations in cellular structure causing changes in protein-protein interaction or in enzymatic activity.

At present, at least three general models have been proposed in order to explain how cells can "sense" these deformations.

A first model can be described by the presence of mechanosensor proteins tethered to cell-cell interaction or cell-extracellular matrix (ECM) interaction, which can feel the deformation of the cellular structure, generating biological signals. The conformational changes in the mechanosensor proteins expose different binding site for other proteins [45]. This model is also called the "Tethered Model". 
In the second model, deformations result directly in an activation of the enzymatic/signalling activity of the proteins that can convert this modification in biological signals.

Finally, a mechanical deformation of the cells can cause a change in the lipid bilayer altering protein-protein interactions, enzymatic activity and architectural intracellular organization. This last model is also called the "lipid bilayer model" [46].

Nevertheless, in the human organisms, several molecular structures have been identified or proposed that are able to primarily "sense" mechanical forces, such as cytoskeleton, extra-cellular matrix, adhesion receptors, extracellular ligands, ion channels, membrane proteins, nuclear pore complex, integrins, $G$ protein coupled-receptors, growth factor receptors etc. [47,48]. In these structures a number of molecules have been identified as "mechanosensor" or "gravireceptors", especially those proteins that show a new conformational state after hyper/hypo-gravity stimuli and that are able to transmit a biochemical signal in the cell, causing adaptation of the cellular functions. Additionally, it has been observed that mechanical cues can also cause post-translational modification, intracellular protein shuttling, protein unfolding generating new interactions, and complex pathobiological effects [49-54].

One of the first site of mechanosensing tightly binds the cellular membrane to the extra-cellular matrix through focal adhesions structure (FAs), characterized by a transmembrane anchoring protein block that establishes complex intracellular relationships with the cytoskeleton. The intracellular part of FA is strictly connected with scaffolding, docking, and signalling (kinases) proteins establishing complex functional and structural connections among the ECM, cell membrane, and cytoskeleton for maintenance of cell shape, internal distribution, and movements of organelles and correct cell proliferation [55]. Focal Adhesions are composed by integral proteins, enzymes, and other accessory proteins, some of which can primarily sense mechanical stress. The integral proteins have the role to interact with molecules of the ECM, such as Fibronectin, Vitronectin, Collagens and Laminins, and other ECM molecules. The composition of ECM and the basement membrane can vary in different tissues and individuals, being a combination of different isoforms of these proteins with variable relative quantity. In this way, every protein can establish different interactions producing different messages and cellular response [56].

Interestingly, the expression of ECM proteins and their adhesive counter-receptors on plasmamembrane can be either constitutive or can be induced by physical (gravity, stretching associated to physical activity, etc.) and biological stimuli (estrogens, TGF- $\beta$, etc.), evidencing the importance of gravity, physical activity and, more in general, of life style.

\section{Mechanosensing in Normogravity}

\subsection{Cytoskeleton/Nucleoskeleton}

These structures provide support to the cells and nucleus to maintain their shape and internal ordered organization. Cytoskeleton and nucleoskeleton are composed by different components such as: actin fibres (F-Actin), myosin and myosin-like filaments, microtubules (MTs), intermediate filaments (IFs), and fibres that interact all together for the maintenance of the cellular architecture and organelle localization and movements [57]. Contractile activity of the cytoskeleton is performed by the actin-myosin system with a number of accessory proteins determining its different organization and function [58]. Isoforms of actin (more than 21 genes plus other isoforms obtained by alternative splicing), tubulin, and myosin (a complex family including skeletal, cardiac, smooth muscle myosins and dynein and many other myosin-like proteins) have in common not only sequence similarities, but also the way to generate the contractile force at the expense of ATP hydrolysis performed by a specific molecular domain of myosin light chain. Different contractile efficiency and vectorial characteristics are determined not only by their supramolecular organization (such as sarcomeres, the fusiform fibres of smooth muscle, the cortical skeleton of plasmamembrane and nucleoskeleton, the tubulin/dynein system in cilia, spermatozoa, and axonal transport). Accessory proteins of cytoskeleton include $\alpha$-actinin, fascin, filamin, and a number of other proteins located in the Z-disk, in the fusiform densities 
of smooth muscle and in the line $\mathrm{M}$ of the sarcomere. All of them are necessary to assembly and maintain more complex supramolecular structures, such as sarcomeres, stress fibres, and microtubular systems [55]. Under mechanical stimuli, stress fibres and focal adhesion plaque interact with sensing and transducing gravity, muscle activity, and stretching. Other proteins can interact with actin, such as Arp2/3, profilin, and ADF/cofilin. Under mechanical stimulation, cofilin is phosphorylated by LIM domain Kinase (LIMK), a kinase activated by the Rho/ROCK pathway [59], a signalling pathway that causes the stabilization of the cytoskeleton through the activation of formin Diaphanous (mDia) and Arp2/3 that in turn produces actin polimerization $[60,61]$.

The proteins described below and included in Table 1, are considered the most well-known mechanosensors acting in normogravity conditions.

Table 1. List of mechanosensors in normogravity conditions and cytosol/nucleus shuttling.

\begin{tabular}{|c|c|c|c|}
\hline \multicolumn{4}{|c|}{ NORMOGRAVITY } \\
\hline PROTEIN & TISSUE/STRUCTURE & Cytosol/Nucleus Shuttling & Reference \\
\hline$\beta$-CATENIN & Cell-Cell adherent junctions & YES & [62-64] \\
\hline Ankrd2 & Sarcomere (Skeletal Muscle) & YES & [65] \\
\hline $\mathrm{c}-\mathrm{Abl}$ & Focal Adhesions & YES & [66] \\
\hline CADHERIN & Cytoskeleton & No Data Available & [43] \\
\hline CARP & Cardiac Muscle & YES & [65] \\
\hline CFTR & RBCs & No Data Available & [67] \\
\hline EMERIN & Integral Membrane Protein & YES & {$[68,69]$} \\
\hline FILAMIN A & Cytoskeleton & YES & [70-72] \\
\hline $\begin{array}{l}\text { FOCAL ADHESION } \\
\text { KINASE (FAK) }\end{array}$ & Cellular membrane/ECM & NO & [73] \\
\hline INTEGRIN $\alpha / \beta$ & Cardiovascular cells, bone etc. & No Data Available & [56] \\
\hline MLP & Muscle & YES & [74] \\
\hline NESPRIN $1 / 2$ & Nucleus & No Data Available & [75] \\
\hline NOMPC or TRPN1 & Ion Channel & No Data Available & [76] \\
\hline NPC & Nuclear pore complex & - & [75] \\
\hline PANNEXIN & RBCs & No Data Available & [77] \\
\hline PAXILLIN & Cytoskeleton & YES & [50] \\
\hline PC1/PC2 complex & Primary bone, Kidney, Liver & No Data Available & [78] \\
\hline PECAM-1 & Endothelial cells & No Data Available & [43] \\
\hline PIEZO1-2 & $\begin{array}{c}\text { Cationic channels, vascular } \\
\text { development/Merkel } \\
\text { cell-neurite complex }\end{array}$ & No Data Available & [79] \\
\hline PTHrP & Parathyroid hormone-related protein & No Data Available & {$[33,80]$} \\
\hline$\beta 1$-SPECTRIN & Muscle cells & No Data Available & [74] \\
\hline SUN1/2 & Nucleus & YES & [75] \\
\hline TALIN/VINCULIN & Cytoskeleton & No Data Available & [54] \\
\hline TREK-TREK2-TRAAK & Ion Channels/Lipid Membrane Bilayer & No Data Available & {$[81,82]$} \\
\hline TITIN & Sarcomere & No Data Available & [65] \\
\hline VIMENTIN & Several cells & No Data Available & [43] \\
\hline Von Willebrand Factor & Platelets & NO & [32] \\
\hline YAP/TAZ & Muscle and epithelial cells & YES & [83] \\
\hline $\mathrm{ZO}-1$ & Membrane protein & YES & [63] \\
\hline ZYXIN & Cytoskeleton & YES & [84-86] \\
\hline
\end{tabular}

RBC, Red Blood Cells; ECM, Extra Cellular Matrix. 
Their KO may or could simulate, at least in part, a condition of absence of gravity, revealing the associated functional/clinical effects. Unfortunately, a loss-of-function $(\mathrm{KO})$ or a gain-of-function of these proteins are still to be explored and compared with animals after long-term space travel.

\section{2. $c-A b l$}

Cells modify their morphology in response to mechanical cues $[87,88]$, although, as mentioned above, the underlying mechanism that controls these changes remains unclear. In this context, Echarri et al. speculated that c-Abl possesses intrinsic mechanosensing activity, strictly related to the phosphorylation of Formin-Binding Protein 17 (FBP17) following plasmamembrane (PM) tension [89]. FBP17, identified as a "membrane curvature regulator" [90] favors the assembly of caveolar rosettes and, according to Echarri's hypothesis, creates an axis with c-Abl tyrosine kinase, or a "kinase-based tension-sensing" pathway, which can control the protein FBP17 in a sensing dependent manner $[89,90]$. In this way, c-Abl is regulated by several stress stimuli [91] as well as by mechanical stimuli.

\subsection{Cadherin}

The cadherin family of receptors represents a group of cell-cell adhesion molecules. Cadherin is a single pass transmembrane protein divided into several subfamilies, many of which are involved in mechanotransduction [92]. Vinculin is a molecule that acts as a co-operator in cadherin-adhesive activity. It shares part of its sequence and structural homology with $\alpha$-catenin and, in this way, activates cadherin mechanotransduction. Cadherin senses changes in tension and causes an adaptative reinforcement of intercellular junctions [93]. Many studies conducted by Benham et al. demonstrated that the activation of Cadherin and the external recruitment of $\beta$-catenin are necessary for the regulation of cell quiescence or proliferation, in concert with the activation of yes-associated protein (YAP) 1 . It is reasonable to define these adhesion structures not only as structural scaffolds activated by mechanical strain but also as signaling centers able to coordinate several responses after applied external stimuli [94].

\subsection{Filamin $A$}

Filamin A is the protein connected with actin and has a major role in cell migration in concert with myosin-like proteins [70]. In the nucleus, Filamin A mediates mechanosensing by interacting with BRCA2 and taking part in the DNA damage response [71]. Furthermore, Filamin A is supposed to mediate mechanosensing by localizing into filopodia, lamellipodia, membrane ruffles, etc., thereby transmuting physical and environmental forces into biochemical signals. Nevertheless, the precise role of Filamin A in these processes remains unclear [72].

\subsection{Focal Adhesion Kinase (FAK)}

Focal Adhesion Kinase (FAK) is a crucial molecule involved in Focal Adhesion (FA) formation after mechanical stimuli. Its activation is strictly related to several external signals that cause its phosphorylation [73], an important event in the downstream signalling pathway by which this protein can control the cytoskeletal structure and reorganization and the nuclei membrane tension and deformation.

\subsection{Ion Channels}

NOMPC (no mechanoreceptor potential C), also called TRPN1, is a mechanosensor channel, discovered in Drosophila, that modifies its conformation and activity after mechanical stimuli. NOMPC also contains 29 ankyrin repeats that can associate to the microtubule network in the dendritic pattern of sensory neurons [76]. Mechanical cues, finally, cause the opening of the pore. Furthermore, TREK-1, a $\mathrm{K}^{+}$channel is considered a mechanosensory, much like TREK-2 and TRAAK in the lipid membrane bilayer of mammals' cells [81,82]. 


\subsection{Paxillin}

Paxillin is a $70 \mathrm{kDa}$ protein localized at focal adhesion level that has the role of integrating the mechanical stimuli of the ECM and the biological signals of the growth factor receptors. This protein exhibits domains, such as LIM, SH2, SH3, and LD, responsible for the high affinity for several structural and signalling partners [95]. In the mechanosensing process paxillin, after being phosphorylated by FAK or Proto-oncogene tyrosine-protein kinase (Src), can bind and activate MAPK signalling [96].

\subsection{Piezo1/2 (Cation Channels)}

Piezo1/2 have been identified as mechanosensors in eukaryotic cells associated with the sense of touch, pressure, and stretch. Piezo 1, together with the cystic fibrosis transmembrane conductance regulator (CFTR) and pannexin-1, is strictly connected with the release of ATP from human red blood cells (RBCs) after mechanical cues $[67,77,97,98]$. However, differently from CFTR and pannexin-1, Piezo1/2 are directly activated without the help of other proteins, a property that is important for the regulation of vascular physiology and for the pathogenesis of hereditary xerocytosis [79].

\subsection{Polycystins (PC1 and PC2) and Primary Cilia}

PC1 and PC2 are expressed in bone tissue where they act as mechanosensors in the entire cellular lineage of bone (preosteoblast, osteoblasts, and osteocytes) [78]. In a singular way, PC1 acts as a mechanosensor, chemoreceptor, and as a sensor in cell-cell or cell-matrix interactions. This protein is tightly bound with FAK and paxillin by activating $G$ proteins and ERK [99] and is also connected with the Wnt signalling [100]. PC1 and PC2 create a complex implicated in mechanosensation in the kidney, liver, and bone, although their role is still unknown [101].

\subsubsection{Talin}

Talin is the first cytoskeletal protein identified as a mechanotransduction factor, connected with the tethered model. It is a cytoskeletal protein that is able to connect focal adhesion with the actin cytoskeleton [102]. Talin is a $270 \mathrm{kDa}$ protein that interacts with F-actin, thus recruiting several proteins, such as Ezrin, Radixin, and Moesin [103]. It can also interact with Vinculin, an important protein connected with focal adhesion. Their interaction depends on the application of forces. In the absence of mechanical stimuli, talin remains totally folded and no sites for Vinculin are available, but in condition of mechanical stresses, they interact creating a system called talin-vinculin mechanosensitivity [54]. To discover these talin properties, several experiments were performed in which the N-terminal of the protein was connected to a glass surface, while the C-terminal was connected to magnetic beads. These beads were tense through magnetic tweezers in the presence of fluorescent molecules. This force increases the number of interactions between vinculin and talin [32].

\subsection{2. $\mathrm{ZO}-1$}

Zonula Occludens-1 (ZO-1) is a cytoplasmatic tight junction (TJ) protein. Tight junctions create barriers in vertebrate organisms that divide compartments of extracellular space [104] and are placed near other molecular structures called "zonula adherens", characterized by the presence of cadherin [105]. ZO-1 is critically important for the bound of actin filaments to the membrane proteins through their C-terminal region and for the contractility of actomyosin cytoskeleton [106,107]. The ZO-1 protein can be in the extended or folded conformation. In the folded conformation, several domains interact, modifying the structure of the protein [108]. Several studies have been conducted in order to determine the effects of mechanical forces on ZO-1 conformation. Recent works demonstrated that ZO-1 is a mechanosensor, depending on the actomyosin-generated force. In fact, ZO-1 is in an extended conformation when its $\mathrm{N}$-terminal and C-terminal are separated, while it is in a folded conformation when the actomyosin mechanical force is absent and a bound between the C-terminal and the central region occurs [109]. 


\subsubsection{Zyxin}

Zyxin is a $61 \mathrm{kDa}$ protein characterized by the presence of the nuclear exclusion sequence domain (NES) and by the ability to be released from FAs in the absence of mechanical cues. However, under mechanical stimuli, Zyxin accumulates in the FAs, causing an actin filament reassembly [84]. Importantly, Zixyn can shuttle to the nucleus and can interact with $\mathrm{p} 130^{\mathrm{Cas}}$, a recently discovered mechanosensor. Zyxin is a LIM protein and can bind MLP, becoming a transcription factor and a mechanotransducer [85]. It can be connected through its domains to several proteins, such as vinculin and FAK in the focal adhesion. Through the interaction with Vinculin, zyxin causes the talin-vinculin assembly [86].

\section{Shuttling Proteins between Cytosol and Nucleus}

In the last decade, mechanosensing have interested the scientific world because of its complexity and for its consequences on cellular activity, related pathways, and response. Interestingly, many proteins identified as mechanosensors can also shuttle between cytosol and nucleus. Examples of this include ZO-1, $\beta$-catenin, and c-Abl. In particular, ZO- 1 accumulates in the nucleus after mechanical stimuli, while c-Abl shuttles from FAs to the nucleus under the same stimuli and finally $\beta$-catenin, localized at the levels of cell-cell adherens junctions, moves to the nucleus after mechanical cues. $\beta$-catenin not only has a structural role but also a transcriptional role as a co-activator $[62,63]$.

\section{Nuclear Mechanotransduction}

As described above, some mechanosensors can shuttle between cytosol and nucleus. The crosstalk between the cytoskeleton and nucleus is very important for the transmission of the mechanical signal from the cytosolic membrane to the nucleus in order to activate a gene response for the adaptation to the external stimuli. Important for this function is LINC (linker of nucleoskeleton and cytoskeleton), which is represented by different proteins, such as SUN1/2 and nesprin1/2. The SUN family of protein can interact with nuclear pore complexes (NPC), thus controlling the morphology and the organization of the nuclear envelope [75].

Emerin has been identified as a tension sensor thanks to its phosphorylation operated by Src that cause its accumulation in the nucleus $[68,69]$. Recently a new signalling pathway involved in mechanotransduction has been identified: the Hippo family composed of Yap and Taz. These factors are involved in stiffness-promoted transcriptional changes. Several pieces of evidence demonstrated that Yap and Taz are localized in the nuclei of epithelial and other cells when cultured on rigid substrates, but are degraded when the same cells are grown on soft substrates [83]. These changes in substrate rigidity cause not only the shift in the localization of Yap and Taz but also the formation of stress fibres, a clear adaptation to the change of substrate. Furthermore, Yap and Taz do not bind actin or other cytoskeletal subunits directly. Instead, they bind directly to the angiomotin that is strictly connected with actin filaments [110]. Ankyrin repeat domain 2 (Ankrd2), also called Ankyrin repeat, the PEST sequence, the proline-rich region (Arpp), Ankyrin repeat domain 1 (Ankrd1)/cardiac Ankyrin repeat protein (CARP), and the diabetes ankyrin repeat protein (DARP) are involved in muscle Ankyrin repeat protein (MARP) mechanosensing that forms a complex with titin/calpain 3 protease/myopalladin [65]. Moreover, cardiac tissue is involved in mechanosensor activity, through the presence of Muscle LIM protein or MLP that translocates to the nucleus where it can bind cardiac transcription factors, such as GATA4. MLP creates a complex with telethonin (TCAP), with titin that can sense the stretching stimuli in cardiac muscle, with $\alpha$-actinin, cofilin-2, and calcineurin. It also creates a tight bound with $\beta 1$-spectrin and zyxin in constamere, specialized structures that sense specific mechanical cues [74]. Finally, PKC $\varepsilon$ is necessary to produce the autophosphorylation of FAK and localizes to Z-bands of cardiomyocytes. PKC $\varepsilon$ shuttles to the nucleus after mechanical stimuli, thus regulating the transcription of $\alpha$-actin [111]. 


\section{Mechanosensing in Microgravity}

Despite the body of evidence regarding the negative effects of microgravity on muscle, bone, cardiac tissue, nervous system, and immunity, we still need to identify the molecular players and pathways responsible for mechanosensing in microgravity. Table 2 reports the most important proteins involved in mechanosensing process in simulated microgravity conditions.

For example, the first system that sense the alteration of gravity, such as microgravity, is the vestibular system in which several changes occur in order to adapt to this new condition. The first mechanism actuated by these structures is to regulate the mass of otoconia and the innervation of sensory epithelium in order to resist to microgravity. This situation is very important for the development of axons and for the projection of the gravity sensors to the brain and spinal cord in which this mechanical signal is interpreted and analysed [112]. The principal aim of this system is to adapt itself to the microgravity conditions in order to establish a new homeostasis and a new balance.

As mentioned above, bone density is also modified by microgravity. Under microgravity conditions, mesenchymal (MSC) cells, which can differentiate in several tissues, such as bone, cartilage, fat, etc., have the trend to differentiate in adipose tissue with the expression of several genes like glut4, adipsin etc. These conditions alter the development of canaliculi that in this way cannot sense the mechanical force that characterizes life on Earth suffering for the free fall in which the body is exposed.

Microgravity also causes several changes in the lungs. Parathyroid hormone-related protein (PTHrP) is essential for the correct development of the lungs [80] and bone tissue [113]. In the lungs, this mechanosensor stimulates the correct alveolar development. In simulated microgravity conditions, the PTHrP signalling pathway is repressed and the concentration of mechanosensor results is very low $[33,114]$. Furthermore, under microgravity, important cytoskeletal changes occur, involving Rho GTPases. In normogravity, cells show a physiological distribution in cytoskeletal components, while in microgravity, microtubules organization is altered with a perinuclear distribution and an altered radial pattern, which is responsible for an incorrect segregation of chromosomes during mitosis. Microgravity also causes a different polymerization and distribution of actin stress fibres and a different pattern of distribution of intermediate filaments. These effects are attributable to a decrease of Rho activity. Several studies conducted by Louis et al. demonstrated that RhoA is strictly connected with the formation of FAs, stress fibres, and with intracellular tension Rac1, another member of the Ras superfamily of small GTP-binding proteins that control actin polymer formation [115]. Moreover, FAs also serve as mechanosensors in arterial remodelling in a rat model subjected to a 4-week hindlimb unweighted (HU) [116].

Nevertheless, cells in microgravity conditions tend to adapt in order to revert this condition and to restore the physiological characteristics that occur in normogravity [117]. Microgravity also causes a transition in myosin heavy chain (MHC) isoforms, with a decrease in the expression of slow type I MHC and an increased expression of fast type IIx MHCin rodents and in humans [13].

As mentioned above, less is known about the connection between mechanosensing and microgravity, but Hayashi et al. demonstrated an upregulation of Kruppel-like factor-4 KLF4 in mammary tissue [118]. This factor is strictly connected with the reprogramming of somatic cells into pluripotent stem cells thanks to the downregulation of DNA methylation. Forkhead box (FOX) proteins are also dysregulated during microgravity with various consequences on proliferation, differentiation, and longevity [119]. 
Table 2. List of Mechanosensors in Microgravity conditions and cytosol/nucleus shuttling. SM, Simulated Microgravity. ISS, International Space Station. RPM, Random Positioning Machine. RCCS, Rotary Cell Culture System.

\begin{tabular}{ccccc}
\hline \multicolumn{5}{c}{ MICROGRAVITY } \\
\hline PROTEIN & TISSUE & SM/ISS & Cytosol/Nucleus Shuttling & References \\
\hline FOX proteins & Several Tissues & SM/RCCS & No Data Available & {$[119]$} \\
\hline KLF4 & $\begin{array}{c}\text { Several Tissues } \\
\text { (Pluripotent Stem Cells) }\end{array}$ & SM/RCCS & No Data Available & {$[118]$} \\
\hline MHC & Muscle & SM & No Data Available & {$[13]$} \\
\hline PTHrP & Lung and Bone & SM/ISS & No Data Available & {$[33,80,113]$} \\
\hline TRPC6 & $\begin{array}{c}\text { Several Tissues } \\
\text { (Intervertebral Discs) }\end{array}$ & SM/RPM & No Data Available & {$[120]$} \\
\hline YAP/TAZ & Several cells & SM/ISS & YES & {$[121-123]$} \\
\hline
\end{tabular}

\subsection{Yap and $\mathrm{Taz}$}

Similar to $\beta$-catenin, yes-associated protein (YAP) and WW domain-containing transcription regulator protein 1 (WWTR1/TAZ) are transcriptional co-activators belonging to the Hippo pathway. YAP and TAZ are shuttled to the nucleus following the mechanical stimulation of the cells, and YAP/TAZ persistence in the nucleus is related to their phosphorylation on specific serine residues operated by LATS1/2 [121]. Furthermore, several studies have demonstrated that YAP/TAZ can be sequestered to the adherent junctions through the cadherin-catenin system and by the activity of ZO-1. YAP and TAZ moreover localize to the nucleus thanks to the interaction with SMAD creating a YAP/TAZ/SMAD complex. In addition, YAP can also shuttle to the nucleus by interacting with ErbB-4 [122].

In cardiac adult cells, the expression of YAP is dysregulated in microgravity conditions. In fact, in normogravity conditions, the Hippo pathway is active while YAP is phosphorylated and barely expressed. On the contrary, in microgravity conditions, the Hippo pathway is inactive and YAP is not phosphorylated and highly expressed [123].

In bone mesenchymal stem cells (BMSCs), simulated microgravity caused a F-actin depolymerization that, in turn, prevented nuclear accumulation of TAZ. Interestingly, the nuclear translocation of TAZ could be prevented by actin stabilizers hasplakinolide or lysophosphatidic acid [124].

\subsection{TRPC6}

An important mechanosensor, tightly bound to gravity changes, is represented by TRPC6. This factor is an ion channel present in several tissues but highly represented in the intervertebral disc cells (IVDs). Evidences obtained with simulated microgravity experiments have underlined a decrease in proliferation of IVD cells with a dysregulation in cell cycle and an increase in cellular senescence [120].

\section{New Candidate Gravireceptors and Future Perspectives}

A series of experiments have been developed in order to establish the presence and the role of gravity-specific mechanosensors. Some of them were conducted on the International Space Station (ISS), while the majority have been performed by simulating microgravity using machineries such as RPM (Random Positioning Machine) or RCCS (Rotary Cell Culture System). Therefore, RPM or RCCS represent the major source of information about the biological effects of microgravity.

Here, we propose exploring two novel possible candidate protein families for gravity sensing and for microgravity adaptation, the LIM protein family (especially MLP) for their important role in mechanosensing in muscle, and SIRTUINS for their important role as protein and histones deacylases, for their ability to control cellular adaptation to external stresses and for their role upon physical activity.

Muscle LIM protein (MLP) belongs to a family of cysteine-rich proteins first observed in cardiac and skeletal muscle [125]. The LIM domain is a cysteine-histidine-rich, zinc-coordinating domain, 
consisting of two zinc fingers [126,127] and conferring specific protein-protein interaction. In particular, MLP cooperates with several proteins, such as titin and telethonin, in order to form anchorage blocks and to maintain the structure of the muscle fibres. MLP is tightly bound to the Z-disk, especially at the periphery where it seals with sarcolemma, cooperating in maintaining the structure and the correct function of contractile apparatus [128,129]. Interestingly, about 10 missense mutations have been reported for MLP. These mutations fall within the first 100 aminoacids and include the first LIM domain and the nuclear localization signal (NLS) [130]. Moreover, two mutations involve two lysines (K) at position 42 and 69. Several MLP mutations have been associated with dilated cardiomyopathy (DCM) and hypertrophic cardiomyopathy (HCM). Lysine 69 is localized in the NLS and the mutation K69R prevents MLP from entering the nucleus [63]. Interestingly, K69 is predicted to be acetylated, therefore, some of the alterations observed in DCM and HCM patients could be due to an aberrant acetylation in the K69R mutant. Another important aspect is that MLP is strictly connected with autophagy, especially in skeletal muscle [131]. Autophagy is an important process that causes the degradation of damaged organelles and proteins in order to promote cellular survival. Unfolded or damaged proteins and damaged organelles are collected in vesicles composed by a double membranous layer, called autophagosomes, which, after fusing with lysosomes, are degraded into their principal units [132].

Less is known about the involvement of these factors in microgravity conditions, but several pieces of evidence led us to speculate a role of these proteins in weightlessness conditions. For example, MLP proteins are strictly connected with the actin cytoskeleton during response to mechanical stimuli together with other important proteins, such as zyxin and paxillin, involved in focal adhesion plaques and stress fibres formation [84].

Under mechanical stimuli, including microgravity, MLP can translocate to the nucleus and bind GATA4, GATA6, AP1, and the serum response factor (SRF) [133]. In long-term microgravity conditions, muscle mass is decreased and the structures of culture myotubes disrupted, an event that, we speculate, would force nuclear localization of MLP. Once in the nucleus, MLP could, however, maintain the vitality of the cells and prepare them for the return to normogravity conditions.

On the other hand, sirtuins, activated by different compounds like resveratrol, honokiol, physical exercise and calorie restriction, are important for the longevity of cells and for the correct development of several structures from microscopic to macroscopic point of view. Their localization varies from cytoplasm (SIRT1,2), mitochondria (SIRT3,4,5), nucleus (SIRT1,6) to nucleolus (SIRT7). Sirtuins have many targets of interaction, in fact, they share a Sir2 catalytic core domain, but possess different sequences at the amino and carboxyl terminus responsible for different localizations and functions $[134,135]$. Sirtuins are also classified for their different activities, such as deacylase at lysine residues and/or mono-ADP-ribosyltransferase on different targets [136,137].

Mammalian sirtuins represent an important bridge between metabolism and epigenetic regulation. For their activity as NAD+-dependent enzymes, sirtuins are cellular metabolic sensors, while their deacylase activity represent an efficient way to modulate the epigenetic status of the genome adapting the organism to the environmental changes [138]. Furthermore, sirtuins present both short-term effects, such as an increase in mitochondriogenesis, $\mathrm{O}_{2}$ consumption, and an increased metabolism in order to maximize the performance, as well as long-term effects tightly connected with increased lifespan, slowing aging, and inflammation control [139].

An interesting point that would deserve a review per se, is the connection between sirtuins, metabolism, and inflammation. In fact, glucose and fatty acid metabolism provides energy to the immune cells for sensing and responding to endogenous and exogenous pathogens $[140,141]$. Sirtuins can regulate the inflammatory response in, at least, two ways: 1) by regulating metabolism using NAD+ as a co-factor and 2) by post translational modification of inflammatory-regulating transcription factors such as NF-kB, STAT3, HIF- $1 \alpha$. However, it must be kept in mind that, in the case of inflammation, the role of sirtuins is very subtle and not always clear. This is probably due to the plethora of sirtuins' targets that complicate the predictivity of the final outcome [142]. Nonetheless, considering that inflammation is activated in microgravity, with an increased production of cytokines such as interferon $\gamma$ (INF- $\gamma$ ) 
and Interleukin 17 (IL-17) [143], a deeper understanding of how sirtuins regulate inflammation may be worth pursuing. In fact, sirtuins' modulation could be used to decrease inflammation and re-tune the immune response in microgravity or during long-term space travel.

Sirtuins, as mentioned above, develop their action in different cell compartments and their expression may change in microgravity or normogravity conditions.

Considering the large number of sirtuin targets and the mutations on two lysines residues of MLP in cardiac muscle diseases reported above [130], we can speculate the presence of a pathway of interaction between sirtuins and MLP mechanosensors. Figure 2 depicts the hypothesis in which MLP and Sirtuins may represent two interacting factors for the long-term response and adaptation to microgravity. Following this model, in normogravity conditions, muscle cell homeostasis is maintained by MLP, that can sense the mechanical cues, including gravity, and by sirtuins that amplify these signals into biological adaptation.

\section{Post-mitotic tissue}

A

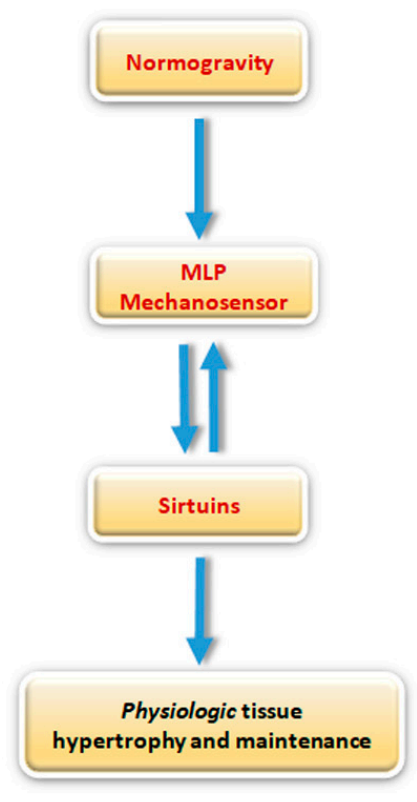

B

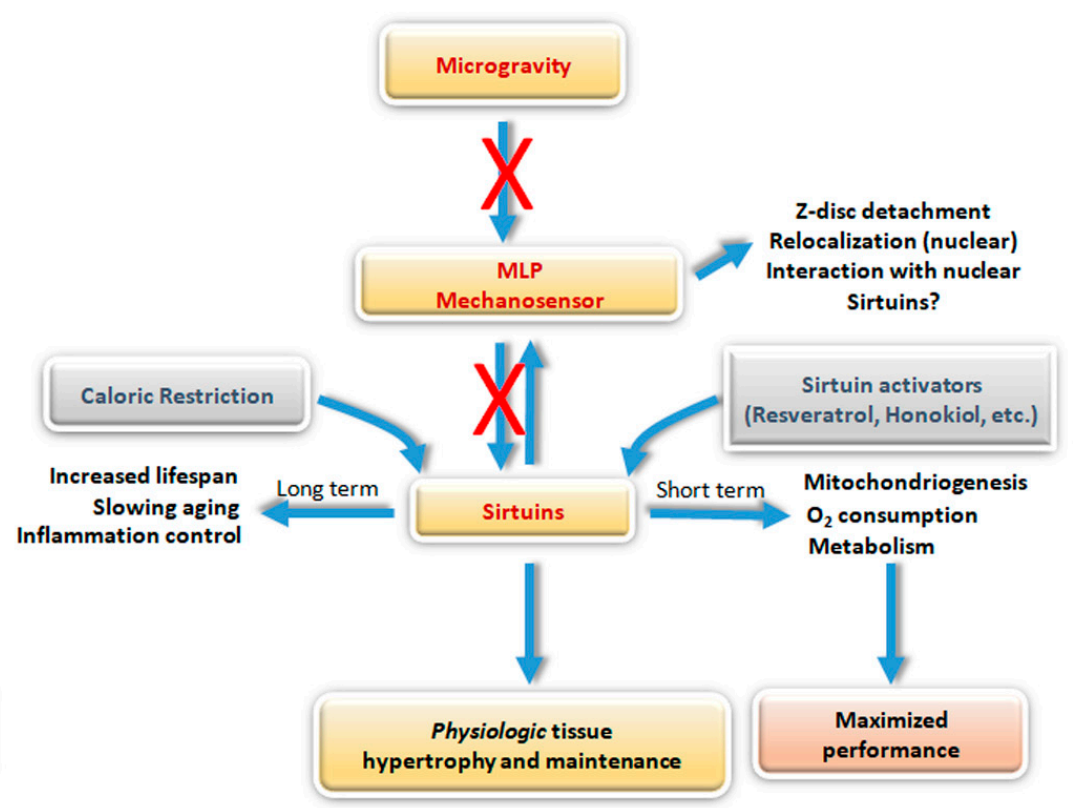

Figure 2. Schematic representation of the possible interaction in post-mitotic cells between the mechanosensor muscle LIM protein (MLP) and sirtuins in normogravity (A) and microgravity (B) condition. (A): Gravity is sensed by MLP that, in muscle cells, resides and contributes to Z-disc maintenance. MLP function is influenced by its interaction with sirtuins that, in turn, controls MLP acylation status. On the other hand, sirtuins integrate other external signals, such as nutrients availability and Reactive Oxygen Species (ROS) levels, to MLP function. Overall, such continuous interaction contributes to the physiology of post mitotic tissues, such as skeletal and cardiac muscle. (B): Reduction or absence of gravity (microgravity) alters Z-disc architecture and MLP localization. MLP may migrate from cytosol to the nucleus. The cytosolic interaction between MLP and sirtuins is lost or reduced. However, in surviving myocytes, nuclear MLP can still interact with nuclear sirtuins forming a complex that can, together with other transcription factors, maintain myocytes vitality while in microgravity and re-activate differentiation once gravity is restored.

In normogravity conditions (Figure 2A) in skeletal and cardiac muscle, there might be an interplay between MPL and sirtuins, as is suggested by mlp-KO or mlp-overexpressing transgenic mice [144]. MLP resides in the sarcomere and has a cytoplasmatic localization ensuring the correct maintenance of the tissue. MLP can sense mechanical stimuli at the level of Z-disc, while sirtuins cooperate by 
sensing metabolic changes, such as ROS level, nutritional changes, or stresses, ions, etc., integrating the adaptive response with mechanical signalling. Additionally, cytosolic sirtuins can perform post-translational modifications (deacylation and/or ADP-ribosylation) on MLP in order to adapt its function and intracellular localization, including the translocation to the nucleus for a muscle-specific gene expression.

Under microgravity conditions (Figure 2B), MLP detaches from the Z-disk and migrates to the nucleus with opposite effects. In the cytosol, the architecture of the Z-disk is weakened and the interactions with the cytosolic sirtuins is lost; however, once in the nucleus, MLP can interact with nuclear sirtuins, thereby acquiring new properties as part of transcription complexes for muscle-specific gene and thus contributing to maintain muscle cell integrity. To this effect, once normogravity is restored, nuclear MLP can be used by the muscle cell to increase Myoblast determination protein (MyoD) and myogenin expression to activate myocyte differentiation to then translocate back to the cytosol to the Z-disk of the forming sarcomere.

This hypothesis accommodates a number of new experimental data and suggests an important role for sirtuins. It is known that sirtuins can be activated by caloric restriction or by natural or synthetic activators, such as SRT1720, resveratrol, honokiol, etc., and in this way they can protect cells, ensuring their vitality and homeostasis through their short- and long-terms effects (Figure 2B). This aspect could be instrumental in protecting skeletal/cardiac muscle cell structure and function by using one or several sirtuin activators during persistent microgravity conditions. Analogously, sirtuins' activators might be used in normogravity to accelerate muscle repair in various human pathological conditions, such as myocardium in dilated cardiomyopathy with myofibrillolysis [145] and skeletal muscle in cachexia.

In conclusion, it would be interesting to investigate if sirtuins can deacetylate MLP on lysine 42 and/or 69 in its cytoplasmic or nuclear localization in order to obtain more information on the possible interplay between these two classes of molecules. Consequently, new studies must be conducted in order to clarify possible sirtuins and MLP interactions and their action in normogravity and microgravity conditions. Furthermore, MLP and sirtuins, can be considered as potential therapeutic targets in order to re-establish the homeostasis after long-term spaceflight. By acting on these proteins, the extension of the spaceflight could be increased and the recovery of the organism homeostasis shortened. In this way, the optimal homeostasis could be restored after prolonged spaceflight in the International Space Station (ISS) or in simulated microgravity conditions.

Author Contributions: Conceptualization, M.A., M.T. and M.A.R.; writing, M.A., F.B., E.V. and M.T.; discussion, M.A., F.B. and M.A.R.; editing, M.A., F.B., E.V., M.B., E.F., M.A.R. and M.T. All authors have read and agreed to the published version of the manuscript.

Funding: This work was supported by grant n. 2015-009-R.0, received from Italian Space Agency (ASI).

Conflicts of Interest: The authors declare no conflict of interest.

\section{References}

1. Van Ombergen, A.; Demertzi, A.; Tomilovskaya, E.; Jeurissen, B.; Sijbers, J.; Kozlovskaya, I.B.; Parizel, P.M.; Van de Heyning, P.H.; Sunaert, S.; Laureys, S.; et al. The effect of spaceflight and microgravity on the human brain. J. Neurol. 2017, 264, 18-22. [CrossRef]

2. Bizzarri, M.; Monici, M.; van Loon, J.J. How microgravity affects the biology of living systems. Biomed. Res. Int. 2015, 2015, 863075. [CrossRef] [PubMed]

3. Antonutto, G.; Di Prampero, P.E. Cardiovascular deconditioning in microgravity: Some possible countermeasures. Eur. J. Appl. Physiol. 2003, 90, 283-291. [CrossRef] [PubMed]

4. Makedonas, G.; Mehta, S.; Choukèr, A.; Simpson, R.J.; Marshall, G.; Orange, J.S.; Aunon-Chancellor, S.; Smith, S.M.; Zwart, S.R.; Stowe, R.P.; et al. Specific Immunologic Countermeasure Protocol for Deep-Space Exploration Missions. Front. Immunol. 2019, 10, 2407. [CrossRef] [PubMed]

5. Mandel, A.D.; Balish, E. Effect of spaceflight on cell mediated immunity. Aviat. Space Environ. Med. 1977, 48, 1051-1057. [PubMed] 
6. Shi, L.; Tian, H.; Wang, P.; Li, L.; Zhang, Z.; Zhang, J.; Zhao, Y. Spaceflight and simulated microgravity suppresses macrophage development via altered RAS/ERK/NFkB and metabolic pathways. Cell Mol. Immunol. 2020. [CrossRef] [PubMed]

7. Tackett, N.; Bradley, J.H.; Moore, E.K.; Baker, S.H.; Minter, S.L.; DiGiacinto, B.; Arnold, J.P.; Gregg, R.K. Prolonged exposure to simulated microgravity diminishes dendritic cell immunogenicity. Sci. Rep. 2019, 9, 13825. [CrossRef]

8. Bradley, J.H.; Stein, R.; Randolph, B.; Molina, E.; Arnold, J.P.; Gregg, R.K. T cell resistance to activation by dendritic cells requires long-term culture in simulated microgravity. Life Sci. Space Res. (Amst.) 2017, 15, 55-61. [CrossRef]

9. Crucian, B.E.; Cubbage, M.L.; Sams, C.F. Altered cytokine production by specific human peripheral blood cell subsets immediately following spaceflight. J. Interferon Cytokine Res. 2000, 20, 547-556. [CrossRef]

10. Voss, E.W., Jr. Prolonged weightlessness and humoral immunity. Science 1984, 225, 214-215. [CrossRef]

11. Baldwin, K.M.; White, T.P.; Arnaud, S.B.; Edgerton, V.R.; Kraemer, W.J.; Kram, R.; Raab-Cullen, D.; Snow, C.M. Musculoskeletal adaptations to weightlessness and development of effective countermeasures. Med. Sci. Sports Exerc. 1996, 28, 1247-1253. [CrossRef]

12. Di Prampero, P.E.; Narici, M.V. Muscles in microgravity: From fibres to human motion. J. Biomech. 2003, 36, 403-412. [CrossRef]

13. Adams, G.R.; Haddad, F.; Baldwin, K.M. The interaction of space flight and thyroid state on somatic and skeletal muscle growth and myosin heavy chain expression on neonatal rodents. J. Gravit. Physiol. 2000, 7, P15-P18. [PubMed]

14. Talmadge, R.J. Myosin heavy chain isoform expression following reduced neuromuscular activity: Potential regulatory mechanisms. Muscle Nerve 2000, 23, 661-679. [CrossRef]

15. Stein, T.P. Nutrition and muscle loss in humans during spaceflight. Adv. Space Biol. Med. 1999, 7, 49-97.

16. Fitts, R.H.; Riley, D.R.; Widrick, J.J. Functional and structural adaptations of skeletal muscle to microgravity. J. Exp. Biol. 2001, 204, 3201-3208. [PubMed]

17. Gardetto, P.R.; Schluter, J.M.; Fitts, R.H. Contractile function of single muscle fibers after hindlimb suspension. J. Appl Physiol (1985) 1989, 66, 2739-2749. [CrossRef] [PubMed]

18. Kandarian, S.C.; Peters, D.G.; Favero, T.G.; Ward, C.W.; Williams, J.H. Adaptation of the skeletal muscle calcium-release mechanism to weight-bearing condition. Am. J. Physiol. 1996, 270, C1588-C1594. [CrossRef] [PubMed]

19. Hikida, R.S.; Gollnick, P.D.; Dudley, G.A.; Convertino, V.A.; Buchanan, P. Structural and metabolic characteristics of human skeletal muscle following 30 days of simulated microgravity. Aviat. Space Environ. Med. 1989, 60, 664-670.

20. Clément, G. The Musculo-Skeletal System in Space. In Fundamentals of Space Medicine; Space Technology Library, Springer: New York, NY, USA, 2011; Volume 23, pp. 181-216.

21. Collet, P.; Uebelhart, D.; Vico, L.; Moro, L.; Hartmann, D.; Roth, M.; Alexandre, C. Effects of 1- and 6-month spaceflight on bone mass and biochemistry in two humans. Bone 1997, 20, 547-551. [CrossRef]

22. Pittenger, M.F.; Mackay, A.M.; Beck, S.C.; Jaiswal, R.K.; Douglas, R.; Mosca, J.D.; Moorman, M.A.; Simonetti, D.W.; Craig, S.; Marshak, D.R. Multilineage potential of adult human mesenchymal stem cells. Science 1999, 284, 143-147. [CrossRef] [PubMed]

23. Engler, A.J.; Sen, S.; Sweeney, H.L.; Discher, D.E. Matrix elasticity directs stem cell lineage specification. Cell 2006, 126, 677-689. [CrossRef] [PubMed]

24. Khayat, G.; Rosenzweig, D.H.; Quinn, T.M. Low frequency mechanical stimulation inhibits adipogenic differentiation of C3H10T1/2 mesenchymal stem cells. Differentiation 2012, 83, 179-184. [CrossRef] [PubMed]

25. Lin, C.; Jiang, X.; Dai, Z.; Guo, X.; Weng, T.; Wang, J.; Li, Y.; Feng, G.; Gao, X.; He, L. Sclerostin mediates bone response to mechanical unloading through antagonizing Wnt/beta-catenin signaling. J. Bone Miner. Res. 2009, 24, 1651-1661. [CrossRef]

26. Segovia-Silvestre, T.; Neutzsky-Wulff, A.V.; Sorensen, M.G.; Christiansen, C.; Bollerslev, J.; Karsdal, M.A.; Henriksen, K. Advances in osteoclast biology resulting from the study of osteopetrotic mutations. Hum. Genet. 2009, 124, 561-577. [CrossRef]

27. Tamma, R.; Colaianni, G.; Camerino, C.; Di Benedetto, A.; Greco, G.; Strippoli, M.; Vergari, R.; Grano, A.; Mancini, L.; Mori, G.; et al. Microgravity during space flight directly affects in vitro osteoclastogenesis and bone resorption. FASEB J. 2009, 23, 2549-2554. [CrossRef] 
28. Gerbaix, M.; Gnyubkin, V.; Farlay, D.; Olivier, C.; Ammann, P.; Courbon, G.; Laroche, N.; Genthial, R.; Follet, H.; Peyrin, F.; et al. One-month space flight compromises the bone microstructure, tissue-level mechanical properties, osteocyte survival and lacunae volume in mature mice skeletons. Sci. Rep. 2017, 7, 2659. [CrossRef]

29. Lafage-Proust, M.H.; Collet, P.; Dubost, J.M.; Laroche, N.; Alexandre, C.; Vico, L. Space-related bone mineral redistribution and lack of bone mass recovery after reambulation in young rats. Am. J. Physiol. 1998, 274, R324-R334. [CrossRef]

30. Keune, J.A.; Branscum, A.J.; Iwaniec, U.T.; Turner, R.T. Effects of Spaceflight on Bone Microarchitecture in the Axial and Appendicular Skeleton in Growing Ovariectomized Rats. Sci. Rep. 2015, 5, 18671. [CrossRef]

31. Puustjärvi, K.; Nieminen, J.; Räsänen, T.; Hyttinen, M.; Helminen, H.J.; Kröger, H.; Huuskonen, J.; Alhava, E.; Kovanen, V. Do more highly organized collagen fibrils increase bone mechanical strength in loss of mineral density after one-year running training? J. Bone Min. Res. 1999, 14, 321-329. [CrossRef]

32. Lim, C.G.; Jang, J.; Kim, C. Cellular machinery for sensing mechanical force. BMB Rep. 2018, 51, $623-629$. [CrossRef] [PubMed]

33. Najrana, T.; Sanchez-Esteban, J. Mechanotransduction as an Adaptation to Gravity. Front. Pediatr. 2016, 4, 140. [CrossRef] [PubMed]

34. Colclasure, J.C.; Holt, J.R. Transduction and adaptation in sensory hair cells of the mammalian vestibular system. Gravit. Space Biol. Bull. 2003, 16, 61-70. [PubMed]

35. Bonewald, L.F. Osteocytes as dynamic multifunctional cells. Ann. NY Acad. Sci. 2007, 1116, $281-290$. [CrossRef] [PubMed]

36. Lanyon, L.E. Osteocytes, strain detection, bone modeling and remodeling. Calcif Tissue Int. 1993, 53, S102-6; discussion S106-7. [CrossRef] [PubMed]

37. Klein-Nulend, J.; Semeins, C.M.; Ajubi, N.E.; Nijweide, P.J.; Burger, E.H. Pulsating fluid flow increases nitric oxide (NO) synthesis by osteocytes but not periosteal fibroblasts-correlation with prostaglandin upregulation. Biochem. Biophys. Res. Commun. 1995, 217, 640-648. [CrossRef]

38. Cherian, P.P.; Siller-Jackson, A.J.; Gu, S.; Wang, X.; Bonewald, L.F.; Sprague, E.; Jiang, J.X. Mechanical strain opens connexin 43 hemichannels in osteocytes: A novel mechanism for the release of prostaglandin. Mol. Biol. Cell. 2005, 16, 3100-3106. [CrossRef]

39. Genetos, D.C.; Kephart, C.J.; Zhang, Y.; Yellowley, C.E.; Donahue, H.J. Oscillating fluid flow activation of gap junction hemichannels induces ATP release from MLO-Y4 osteocytes. J. Cell Physiol. 2007, 212, 207-214. [CrossRef]

40. Lu, X.L.; Huo, B.; Park, M.; Guo, X.E. Calcium response in osteocytic networks under steady and oscillatory fluid flow. Bone 2012, 51, 466-473. [CrossRef]

41. Luu, Y.K.; Capilla, E.; Rosen, C.J.; Gilsanz, V.; Pessin, J.E.; Judex, S.; Rubin, C.T. Mechanical stimulation of mesenchymal stem cell proliferation and differentiation promotes osteogenesis while preventing dietary-induced obesity. J. Bone Miner. Res. 2009, 24, 50-61. [CrossRef]

42. Song, G.; Ju, Y.; Soyama, H.; Ohashi, T.; Sato, M. Regulation of cyclic longitudinal mechanical stretch on proliferation of human bone marrow mesenchymal stem cells. Mol. Cell Biomech. 2007, 4, 201-210. [PubMed]

43. Coon, B.G.; Baeyens, N.; Han, J.; Budatha, M.; Ross, T.D.; Fang, J.S.; Yun, S.; Thomas, J.L.; Schwartz, M.A. Intramembrane binding of VE-cadherin to VEGFR2 and VEGFR3 assembles the endothelial mechanosensory complex. J. Cell Biol. 2015, 8, 975-986. [CrossRef] [PubMed]

44. Nesbitt, W.S.; Westein, E.; Tovar-Lopez, F.J.; Tolouei, E.; Mitchell, A.; Fu, J.; Carberry, J.; Fouras, A.; Jackson, S.P. A shear gradient-dependent platelet aggregation mechanism drives thrombus formation. Nat. Med. 2009, 15, 665-673. [CrossRef] [PubMed]

45. Hu, X.; Margadant, F.M.; Yao, M.; Sheetz, M.P. Molecular stretching modulates mechanosensing pathways. Protein Sci. 2017, 26, 1337-1351. [CrossRef] [PubMed]

46. Haswell, E.S.; Phillips, R.; Rees, D.C. Mechanosensitive channels: What can they do and how do they do it? Structure 2011, 19, 1356-1369. [CrossRef]

47. Martinac, B. The ion channels to cytoskeleton connection as potential mechanism of mechanosensitivity. Biochim. Biophys. Acta 2014, 1838, 682-691. [CrossRef]

48. Bizzarri, M.; Cucina, A.; Palombo, A.; Masiello, M.G. Gravity sensing by cells: Mechanisms and theoretical grounds. Rend. Fis. Acc. Lincei 2014, 25, 29-38. [CrossRef] 
49. Sawada, Y.; Tamada, M.; Dubin-Thaler, B.J.; Cherniavskaya, O.; Sakai, R.; Tanaka, S.; Sheetz, M.P. Force sensing by mechanical extension of the Src family kinase substrate p130Cas. Cell 2006, 127, 1015-1026. [CrossRef]

50. Dong, J.M.; Lau, L.S.; Ng, Y.W.; Lim, L.; Manser, E. Paxillin nuclear-cytoplasmic localization is regulated by phosphorylation of the LD4 motif: Evidence that nuclear paxillin promotes cell proliferation. Biochem. J. 2009, 418, 173-184. [CrossRef]

51. Gumbiner, B.M.; Yamada, K.M. Cell-to-cell contact and extracellular matrix. Curr. Opin. Cell Biol. 1995, 7 , 615-618. [CrossRef]

52. Gottardi, C.J.; Arpin, M.; Fanning, A.S.; Louvard, D. The junction-associated protein, zonula occludens-1, localizes to the nucleus before the maturation and during the remodeling of cell-cell contacts. Proc. Natl. Acad. Sci. USA 1996, 93, 10779-10784. [CrossRef]

53. Del Rio, A.; Perez-Jimenez, R.; Liu, R.; Roca-Cusachs, P.; Fernandez, J.M.; Sheetz, M.P. Stretching single talin rod molecules activates vinculin binding. Science 2009, 323, 638-641. [CrossRef]

54. Humphries, J.D.; Wang, P.; Streuli, C.; Geiger, B.; Humphries, M.J.; Ballestrem, C. Vinculin controls focal adhesion formation by direct interactions with talin and actin. J. Cell Biol. 2007, 179, 1043-1057. [CrossRef] [PubMed]

55. Martino, F.; Perestrelo, A.R.; Vinarský, V.; Pagliari, S.; Forte, G. Cellular Mechanotransduction: From Tension to Function. Front. Physiol. 2018, 9, 824. [CrossRef]

56. Seetharaman, S.; Etienne-Manneville, S. Integrin diversity brings specificity in mechanotransduction. Biol. Cell 2018, 110, 49-64. [CrossRef] [PubMed]

57. Chen, T.J.; Wu, C.C.; Tang, M.J.; Huang, J.S.; Su, F.C. Complexity of the tensegrity structure for dynamic energy and force distribution of cytoskeleton during cell spreading. PLoS ONE 2010, 5, e14392. [CrossRef] [PubMed]

58. Mohan, R.; John, A. Microtubule-associated proteins as direct crosslinkers of actin filaments and microtubules. IUBMB Life 2015, 67, 395-403. [CrossRef]

59. Fukata, Y.; Amano, M.; Kaibuchi, K. Rho-Rho-kinase pathway in smooth muscle contraction and cytoskeletal reorganization of non-muscle cells. Trends Pharm. Sci. 2001, 22, 32-39. [CrossRef]

60. Palazzo, A.F.; Cook, T.A.; Alberts, A.S.; Gundersen, G.G. mDia mediates Rho-regulated formation and orientation of stable microtubules. Nat. Cell Biol. 2001, 3, 723-729. [CrossRef]

61. Zigmond, S.H. Beginning and ending an actin filament: Control at the barbed end. Curr. Top. Dev. Biol. 2004, 63, 145-188.

62. Gumbiner, B.M. Signal transduction of beta-catenin. Curr. Opin. Cell Biol. 1995, 7, 634-640. [CrossRef]

63. Schwayer, C.; Shamipour, S.; Pranjic-Ferscha, K.; Schauer, A.; Balda, M.; Tada, M.; Matter, K.; Heisenberg, C.P. Mechanosensation of Tight Junctions Depends on ZO-1 Phase Separation and Flow. Cell 2019, 179, 937-952. [CrossRef] [PubMed]

64. Tzima, E.; Irani-Tehrani, M.; Kiosses, W.B.; Dejana, E.; Schultz, D.A.; Engelhardt, B.; Cao, G.; DeLisser, H.; Schwartz, M.A. A mechanosensory complex that mediates the endothelial cell response to fluid shear stress. Nature 2005, 437, 426-431. [CrossRef] [PubMed]

65. Belgrano, A.; Rakicevic, L.; Mittempergher, L.; Campanaro, S.; Martinelli, V.C.; Mouly, V.; Valle, G.; Kojic, S.; Faulkner, G. Multi-tasking role of the mechanosensing protein Ankrd2 in the signaling network of striated muscle. PLoS ONE 2011, 6, e25519. [CrossRef]

66. Lewis, J.M.; Baskaran, R.; Taagepera, S.; Schwartz, M.A.; Wang, J.Y. Integrin regulation of c-Abl tyrosine kinase activity and cytoplasmic-nuclear transport. Proc. Natl. Acad. Sci. USA 1996, 93, 15174-15179. [CrossRef]

67. Sprague, R.S.; Ellsworth, M.L.; Stephenson, A.H.; Kleinhenz, M.E.; Lonigro, A.J. Deformation-induced ATP release from red blood cells requires CFTR activity. Am. J. Physiol. 1998, 275, H1726-H1732. [CrossRef]

68. Guilluy, C.; Osborne, L.D.; Van Landeghem, L.; Sharek, L.; Superfine, R.; Garcia-Mata, R.; Burridge, K. Isolated nuclei adapt to force and reveal a mechanotransduction pathway in the nucleus. Nat. Cell Biol. 2014, 16, 376-381. [CrossRef]

69. Osmanagic-Myers, S.; Dechat, T.; Foisner, R. Lamins at the crossroads of mechanosignaling. Genes Dev. 2015, 29, 225-237. [CrossRef]

70. Feng, Y.; Walsh, C.A. The many faces of filamin: A versatile molecular scaffold for cell motility and signalling. Nat. Cell Biol. 2004, 6, 1034-1038. [CrossRef] 
71. Yuan, Y.; Shen, Z. Interaction with BRCA2 suggests a role for filamin-1 (hsFLNa) in DNA damage response. J. Biol Chem. 2001, 276, 48318-48324. [CrossRef]

72. Razinia, Z.; Mäkelä, T.; Ylänne, J.; Calderwood, D.A. Filamins in mechanosensing and signalling. Annu. Rev. Biophys. 2012, 41, 227-246. [CrossRef] [PubMed]

73. Michael, K.E.; Dumbauld, D.W.; Burns, K.L.; Hanks, S.K.; García, A.J. Focal adhesion kinase modulates cell adhesion strengthening via integrin activation. Mol. Biol Cell. 2009, 20, 2508-2519. [CrossRef] [PubMed]

74. Buyandelger, B.; Ng, K.E.; Miocic, S.; Piotrowska, I.; Gunkel, S.; Ku, C.H.; Knöll, R. MLP (muscle LIM protein) as a stress sensor in the heart. Pflug. Arch. 2011, 462, 135-142. [CrossRef] [PubMed]

75. Liu, Q.; Pante, N.; Misteli, T.; Elsagga, M.; Crisp, M.; Hodzic, D.; Burke, B.; Roux, K.J. Functional association of Sun1 with nuclear pore complexes. J. Cell Biol. 2007, 178, 785-798. [CrossRef]

76. Walker, R.G.; Willingham, A.T.; Zuker, C.S. A Drosophila mechanosensory transduction channel. Science 2000, 287, 2229-2234. [CrossRef]

77. Locovei, S.; Bao, L.; Dahl, G. Pannexin 1 in erythrocytes: Function without a gap. Proc. Natl. Acad. Sci. USA 2006, 103, 7655-9765. [CrossRef]

78. Xiao, Z.S.; Quarles, L.D. Role of the polycytin-primary cilia complex in bone development and mechanosensing. Ann. NY Acad Sci. 2010, 1192, 410-421. [CrossRef]

79. Cinar, E.; Zhou, S.; DeCourcey, J.; Wang, Y.; Waugh, R.E.; Wan, J. Piezo1 regulates mechanotransductive release of ATP from human RBCs. Proc. Natl. Acad. Sci. USA 2015, 112, 11783-11788. [CrossRef]

80. Karperien, M.; Lanser, P.; de Laat, S.W.; Boonstra, J.; Defize, L.H. Parathyroid hormone related peptide mRNA expression during murine postimplantation development: Evidence for involvement in multiple differentiation processes. Int. J. Dev. Biol. 1996, 40, 599-608.

81. Maingret, F.; Patel, A.J.; Lesage, F.; Lazdunski, M.; Honoré, E. Mechano- or acid stimulation, two interactive modes of activation of the TREK-1 potassium channel. J. Biol Chem. 1999, 274, 26691-26696. [CrossRef]

82. Lesage, F.; Maingret, F.; Lazdunski, M. Cloning and expression of human TRAAK, a polyunsaturated fatty acids-activated and mechano-sensitive $\mathrm{K}(+)$ channel. FEBS Lett. 2000, 471, 137-140. [CrossRef]

83. Dupont, S.; Morsut, L.; Aragona, M.; Enzo, E.; Giulitti, S.; Cordenonsi, M.; Zanconato, F.; Le Digabel, J.; Forcato, M.; Bicciato, S.; et al. Role of YAP/TAZ in mechanotransduction. Nature 2011, 474, $179-183$. [CrossRef] [PubMed]

84. Yoshigi, M.; Hoffman, L.M.; Jensen, C.C.; Yost, H.J.; Beckerle, M.C. Mechanical force mobilizes zyxin from focal adhesions to actin filaments and regulates cytoskeletal reinforcement. J. Cell Biol. 2005, 171, 209-215. [CrossRef] [PubMed]

85. Louis, H.A.; Pino, J.D.; Schmeichel, K.L.; Pomiès, P.; Beckerle, M.C. Comparison of three members of the cysteine-rich protein family reveals functional conservation and divergent patterns of gene expression. J. Biol. Chem. 1997, 272, 27484-27491. [CrossRef]

86. Janoštiak, R.; Brábek, J.; Auernheimer, V.; Tatárová, Z.; Lautscham, L.A.; Dey, T.; Gemperle, J.; Merkel, R.; Goldmann, W.H.; Fabry, B.; et al. CAS directly interacts with vinculin to control mechanosensing and focal adhesion dynamics. Cell Mol. Life Sci. 2014, 71, 727-744. [CrossRef]

87. Mammoto, T.; Ingber, D.E. Mechanical control of tissue and organ development. Development 2010, 137, 1407-1420. [CrossRef]

88. Burridge, K.; Wittchen, E.S. The tension mounts: Stress fibers as force generating mechanotransducers. J. Cell Biol. 2013, 200, 9-19. [CrossRef]

89. Echarri, A.; Pavón, D.M.; Sánchez, S.; García-García, M.; Calvo, E.; Huerta-López, C.; Velázquez-Carreras, D.; Viaris de Lesegno, C.; Ariotti, N.; Lázaro-Carrillo, A.; et al. An Abl-FBP17 mechanosensing system couples local plasma membrane curvature and stress fiber remodeling during mechanoadaptation. Nat. Commun. 2019, 10, 5828. [CrossRef]

90. Echarri, A.; Muriel, O.; Pavón, D.M.; Azegrouz, H.; Escolar, F.; Terrón, M.C.; Sanchez-Cabo, F.; Martínez, F.; Montoya, M.C.; Llorca, O.; et al. Caveolar domain organization and trafficking is regulated by Abl kinases and mDia1. J. Cell Sci. 2012, 125, 3097-3113. [CrossRef]

91. Khatri, A.; Wang, J.; Pendergast, A.M. Multifunctional Abl kinases in health and disease. J. Cell Sci. 2016, 129, 9-16. [CrossRef]

92. Niessen, C.M.; Leckband, D.; Yap, A.S. Tissue organization by cadherin adhesion molecules: Dynamic molecular and cellular mechanisms of morphogenetic regulation. Physiol Rev. 2011, 91, 691-731. [CrossRef] [PubMed] 
93. Leckband, D.E.; de Rooij, J. Cadherin adhesion and mechanotransduction. Annu. Rev. Cell Dev. Biol. 2014, 30, 291-315. [CrossRef]

94. Benham-Pyle, B.W.; Pruitt, B.L.; Nelson, W.J. Cell adhesion. Mechanical strain induces E-cadherin-dependent Yap1 and $\beta$-catenin activation to drive cell cycle entry. Science 2015, 348, 1024-1027. [CrossRef] [PubMed]

95. Kadrmas, J.L.; Beckerle, M.C. The LIM domain: From the cytoskeleton to the nucleus. Nat. Rev. Mol. Cell Biol. 2004, 5, 920-931. [CrossRef] [PubMed]

96. Bae, Y.H.; Mui, K.L.; Hsu, B.Y.; Liu, S.L.; Cretu, A.; Razinia, Z.; Xu, T.; Puré, E.; Assoian, R.K. A FAK-Cas-Rac-lamellipod in signaling module transduces extracellular matrix stiffness into mechanosensitive cell cycling. Sci. Signal. 2014, 7, ra57. [CrossRef]

97. Wan, J.; Ristenpart, W.D.; Stone, H.A. Dynamics of shear-induced ATP release from red blood cells. Proc. Natl. Acad. Sci. USA 2008, 105, 16432-16437. [CrossRef]

98. Gov, N.S.; Safran, S.A. Red blood cell membrane fluctuations and shape controlled by ATP-induced cytoskeletal defects. Biophys. J. 2005, 88, 1859-1874. [CrossRef]

99. Low, S.H.; Vasanth, S.; Larson, C.H.; Mukherjee, S.; Sharma, N.; Kinter, M.T.; Kane, M.E.; Obara, T.; Weimbs, T. Polycystin-1, STAT6, and P100 function in a pathway that transduces ciliary mechanosensation and is activated in polycystic kidney disease. Dev. Cell. 2006, 10, 57-69. [CrossRef]

100. Moon, R.T.; Kohn, A.D.; De Ferrari, G.V.; Kaykas, A. WNT and beta-catenin signalling: Diseases and therapies. Nat. Rev. Genet. 2004, 5, 691-701. [CrossRef]

101. Xiao, Z.; Zhang, S.; Mahlios, J.; Zhou, G.; Magenheimer, B.S.; Guo, D.; Dallas, S.L.; Maser, R.; Calvet, J.P.; Bonewald, L.; et al. Cilia-like structures and polycystin-1 in osteoblasts/osteocytes and associated abnormalities in skeletogenesis and Runx2 expression. J. Biol. Chem. 2006, 281, 30884-30895. [CrossRef]

102. Horwitz, A.; Duggan, K.; Buck, C.; Beckerle, M.C.; Burridge, K. Interaction of plasma membrane fibronectin receptor with talin-a transmembrane linkage. Nature 1986, 320, 531-533. [CrossRef]

103. Ciobanasu, C.; Wang, H.; Henriot, V.; Mathieu, C.; Fente, A.; Csillag, S.; Vigouroux, C.; Faivre, B.; Le Clainche, C. Integrin-bound talin head inhibits actin filament barbed-end elongation. J. Biol. Chem. 2018, 293, 2586-2596. [CrossRef]

104. Anderson, J.M.; Van Itallie, C.M. Physiology and function of the tight junction. Cold Spring Harb. Perspect. Biol. 2009, 1, 1-16. [CrossRef]

105. Zihni, C.; Mills, C.; Matter, K.; Balda, M.S. Tight junctions: From simple barriers to multifunctional molecular gates. Nat. Rev. Mol. Cell Biol. 2016, 17, 564-580. [CrossRef]

106. Itoh, M.; Nagafuchi, A.; Moroi, S.; Tsukita, S. Involvement of ZO-1 in cadherin-based cell adhesion through its direct binding to alpha catenin and actin filaments. J. Cell Biol. 1997, 138, 181-192. [CrossRef]

107. Van Itallie, C.M.; Fanning, A.S.; Bridges, A.; Anderson, J.M. ZO-1 stabilizes the tight junction solute barrier through coupling to the perijunctional cytoskeleton. Mol. Biol Cell. 2009, 20, 3930-3940. [CrossRef]

108. Rouaud, F.; Vasileva, E.; Spadaro, D.; Tsukita, S.; Citi, S. R40.76 binds to the $\alpha$ domain of ZO-1: Role of ZO-1 $(\alpha+)$ in epithelial differentiation and mechano-sensing. Tissue Barriers 2019, 7, e1653748. [CrossRef] [PubMed]

109. Spadaro, D.; Le, S.; Laroche, T.; Mean, I.; Jond, L.; Yan, J.; Citi, S. Tension-dependent stretching activates ZO-1 to control the junctional localization of its interactors. Curr. Biol. 2017, 27, 3783-3795. [CrossRef] [PubMed]

110. Chan, S.W.; Lim, C.J.; Chong, Y.F.; Pobbati, A.V.; Huang, C.; Hong, W. Hippo pathway-independent restriction of TAZ and YAP by angiomotin. J. Biol. Chem. 2011, 286, 7018-7026. [CrossRef] [PubMed]

111. Wu, G.; Toyokawa, T.; Hahn, H.; Dorn, G.W., 2nd. Epsilon protein kinase C in pathological myocardial hypertrophy. Analysis by combined transgenic expression of translocation modifiers and Galphaq. J. Biol. Chem. 2000, 275, 29927-29930. [CrossRef] [PubMed]

112. Jamon, M. The development of vestibular system and related functions in mammals: Impact of gravity. Front. Integr. Neurosci. 2014, 7, 8-11. [CrossRef] [PubMed]

113. Camirand, A.; Goltzman, D.; Gupta, A.; Kaouass, M.; Panda, D.; Karaplis, A. The Role of Parathyroid Hormone-Related Protein (PTHrP) in Osteoblast Response to Microgravity: Mechanistic Implications for Osteoporosis Development. PLoS ONE 2016, 11, e0160034. [CrossRef] [PubMed]

114. Torday, J.S. Parathyroid hormone-related protein is a gravisensor in lung and bone cell biology. Adv. Space Res. 2003, 32, 1569-1576. [CrossRef]

115. Louis, F.; Deroanne, C.; Nusgens, B.; Vico, L.; Guignandon, A. RhoGTPases as key players in mammalian cell adaptation to microgravity. Biomed. Res. Int. 2015, 747693, 17. [CrossRef] 
116. Jiang, M.; Lyu, Q.; Bai, Y.G.; Liu, H.; Yang, J.; Cheng, J.H.; Zheng, M.; Ma, J. Focal adhesions are involved in simulated-microgravity-induced basilar and femoral arterial remodelling in rats. Can. J. Physiol. Pharm. 2018, 96, 772-782. [CrossRef] [PubMed]

117. Hlavacka, F.; Dzurkova, O.; Kornilova, L.N. Vestibular and somatosensory interaction during recovery of balance instability after spaceflight. J. Gravit. Physiol. 2001, 8, 89-92.

118. Hayashi, K.; Sasamura, H.; Nakamura, M.; Azegami, T.; Oguchi, H.; Sakamaki, Y.; Itoh, H. KLF4-dependent epigenetic remodeling modulates podocyte phenotypes and attenuates proteinuria. J. Clin. Investig. 2014, 124, 2523-2537. [CrossRef]

119. Arun, R.P.; Sivanesan, D.; Vidyasekar, P.; Verma, R.S. PTEN/FOXO3/AKT pathway regulates cell death and mediates morphogenetic differentiation of Colorectal Cancer Cells under Simulate Microgravity. Sci. Rep. 2017, 7, 5952. [CrossRef]

120. Franco-Obregón, A.; Cambria, E.; Greutert, H.; Wernas, T.; Hitzl, W.; Egli, M.; Sekiguchi, M.; Boos, N.; Hausmann, O.; Ferguson, S.J.; et al. TRPC6 in simulated microgravity of intervertebral disc cells. Eur. Spine J. 2018, 27, 2621-2630. [CrossRef]

121. Mosqueira, D.; Pagliari, S.; Uto, K.; Ebara, M.; Romanazzo, S.; Escobedo-Lucea, C.; Nakanishi, J.; Taniguchi, A.; Franzese, O.; Di Nardo, P.; et al. Hippo pathway effectors control cardiac progenitor cell fate by acting as dynamic sensors of substrate mechanics and nanostructure. Acs Nano 2014, 25, 2033-2047. [CrossRef]

122. Komuro, A.; Nagai, M.; Navin, N.E.; Sudol, M. WW domain-containing protein YAP associates with ErbB-4 and acts as a co-transcriptional activator for the carboxyl-terminal fragment of ErbB-4 that translocates to the nucleus. J. Biol. Chem. 2003, 278, 33334-33341. [CrossRef]

123. Camberos, V.; Baio, J.; Bailey, L.; Hasaniya, N.; Lopez, L.V.; Kearns-Jonker, M. Effects of Spaceflight and Simulated Microgravity on YAP1 Expression in Cardiovascular Progenitors: Implications for Cell-Based Repair. IJMS 2019, 20, 2742. [CrossRef]

124. Chen, Z.; Luo, Q.; Lin, C.; Kuang, D.; Song, G. Simulated microgravity inhibits osteogenic differentiation of mesenchymal stem cells via depolymerizing F-actin to impede TAZ nuclear translocation. Sci. Rep. 2016, 6, 30322. [CrossRef]

125. Rashid, M.M.; Runci, A.; Polletta, L.; Carnevale, I.; Morgante, E.; Foglio, E.; Arcangeli, T.; Sansone, L.; Russo, M.A.; Tafani, M. Muscle LIM protein/CSRP3: A mechanosensor with a role in autophagy. Cell Death Discov. 2015, 3, 15014. [CrossRef]

126. Dawid, I.B.; Breen, J.J.; Toyama, R. LIM domains: Multiple roles as adapters and functional modifiers in protein interactions. Trends Genet. 1998, 14, 156-162. [CrossRef]

127. Jurata, L.W.; Gill, G.N. Structure and function of LIM domains. Curr. Top. Microbiol. Immunol. 1998, 228, 75-113.

128. Arber, S.; Caroni, P. Specificity of single LIM motifs in targeting and LIM/LIM interactions in situ. Genes Dev. 1996, 10, 289-300. [CrossRef] [PubMed]

129. Kong, Y.; Flick, M.J.; Kudla, A.J.; Konieczny, S.F. Muscle LIM protein promotes myogenesis by enhancing the activity of MyoD. Mol. Cell Biol. 1997, 17, 4750-4760. [CrossRef] [PubMed]

130. Vafiadaki, E.; Arvanitis, D.A.; Sanoudou, D. Muscle LIM Protein: Master regulator of cardiac and skeletal muscle functions. Gene 2015, 566, 1-7. [CrossRef] [PubMed]

131. Rashid, M.M.; Runci, A.; Russo, M.A.; Tafani, M. Muscle Lim Protein (MLP)/CSRP3 at the crossroad between mechanotransduction and autophagy. Cell Death Dis. 2015, 22, e1940. [CrossRef] [PubMed]

132. Mizushima, N.; Komatsu, M. Autophagy: Renovation of cells and tissues. Cell 2011, 147, 728-741. [CrossRef] [PubMed]

133. Chang, D.F.; Belaguli, N.S.; Iyer, D.; Roberts, W.B.; Wu, S.P.; Dong, X.R.; Marx, J.G.; Moore, M.S.; Beckerle, M.C.; Majesky, M.W.; et al. Cysteine-rich LIM-only proteins CRP1 and CRP2 are potent smooth muscle differentiation cofactors. Dev. Cell. 2003, 4, 107-118. [CrossRef]

134. North, B.J.; Verdin, E. Sirtuins: Sir2-related NAD-dependent protein deacetylases. Genome Biol. 2004, 5, 224. [CrossRef] [PubMed]

135. Guarente, L. Sir2 links chromatin silencing, metabolism, and aging. Genes Dev. 2000, 14, 1021-1026.

136. Du, J.; Zhou, Y.; Su, X.; Yu, J.J.; Khan, S.; Jiang, H.; Kim, J.; Woo, J.; Kim, J.H.; Choi, B.H.; et al. Sirt5 is a NAD-dependent protein lysine demalonylase and desuccinylase. Science 2011, 334, 806-809. [CrossRef] [PubMed] 
137. Frye, R.A. Characterization of five human cDNAs with homology to the yeast SIR2 gene: Sir2-like proteins (sirtuins) metabolize NAD and may have protein ADP-ribosyltransferase activity. Biochem. Biophys. Res. Commun. 1999, 260, 273-279. [CrossRef]

138. Kosciuk, T.; Wang, M.; Hong, J.Y.; Lin, H. Updates on the epigenetic roles of sirtuins. Curr. Opin. Chem. Biol. 2019, 51, 18-29. [CrossRef]

139. Vachharajani, V.T.; Liu, T.; Wang, X.; Hoth, J.J.; Yoza, B.K.; McCall, C.E. Sirtuins Link Inflammation and Metabolism. J. Immunol. Res. 2016, 8167273. [CrossRef]

140. Liu, T.F.; Brown, C.M.; El Gazzar, M.; McPhail, L.; Millet, P.; Rao, A.; Vachharajani, V.T.; Yoza, B.K.; McCall, C.E. Fueling the flame: Bioenergy couples metabolism and inflammation. J. Leukoc Biol. 2012, 92, 499-507. [CrossRef]

141. McGettrick, A.F.; O'Neill, L.A. How metabolism generates signals during innate immunity and inflammation. J. Biol. Chem. 2013, 288, 22893-22898. [CrossRef]

142. Gallí, M.; Van Gool, F.; Leo, O. Sirtuins and inflammation: Friends or foes? Biochem Pharm. 2011, 81, 569-876. [CrossRef] [PubMed]

143. Chang, T.T.; Spurlock, S.M.; Candelario, T.L.; Grenon, S.M.; Hughes-Fulford, M. Spaceflight impairs antigen-specific tolerance induction in vivo and increases inflammatory cytokines. FASEB J. 2015, 29, 4122-4132. [CrossRef] [PubMed]

144. Michaelides, M.; Georgiadou, S.; Constantinides, C. In vivo epicardial force and strain characterisation in normal and MLP-knockout murine hearts. Physiol. Meas. 2015, 36, 1573-1590. [CrossRef]

145. Bugger, H.; Witt, C.N.; Bode, C. Mitochondrial sirtuins in the heart. Heart Fail. Rev. 2016, 21, 519-528. [CrossRef] [PubMed]

(C) 2020 by the authors. Licensee MDPI, Basel, Switzerland. This article is an open access article distributed under the terms and conditions of the Creative Commons Attribution (CC BY) license (http://creativecommons.org/licenses/by/4.0/). 